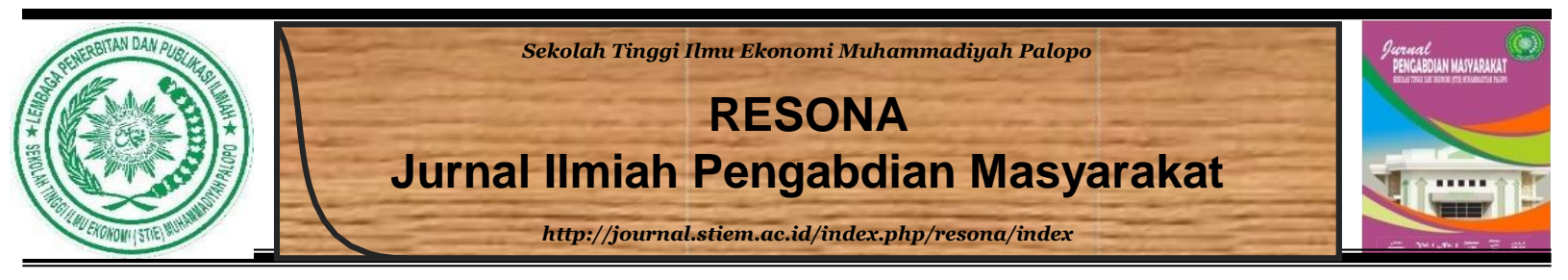

\title{
Sosialisasi Pemanfaatan Limbah Rumput Laut Sebagai Bahan Dasar Pembuatan Pakan Dan Pupuk Organik Di Desa Benteng Kecamatan Malangke Kabupaten Luwu Utara
}

\author{
${ }^{1}$ A.Dahri Adi Patra Ls, ${ }^{2}$ I Ketut Patra \\ ${ }^{1,2}$ STIE Muhammadiyah Palopo
}

INFO NASKAH

Diserahkan

11 maret 2018

Diterima

28 mei 2018

Diterima dan Disetujui

18 Juni 2018

\section{Kata Kunci:}

Sosialisasi, pakan, pupuk organki, limbah rumput laut, permentan no 70/2011

\begin{abstract}
ABSTRAK
Kegiatan pengabdian ini bertujuan untuk mensoalisasikan Peraturan Menter iPertanian Nomor 70 tahun 2011 tentang Pupuk Organik serta sosialisasi pemanfaatan Limbah Rumput Laut sebagai bahan dasar pembuatan pakan dan pupuk organik di Desa Benteng Kecamatan Malangke Kabupaten Luwu Utara. Kabupaten Luwu Utara mempunyai potensi sebagai penghasil udang, ikan dan rumput laut yang cukup besar, namun dibalik potensi tersebut terdapat potensi masalah berupa limbah rumput laut jika tidak dikelola denga baik, dapat menjadii ancaman terhadap lingkungan disekitar tambak, gudang dan tempat produksi. Hasil penelitian LPPMHP Kementerian Kelautan dan Perikanan dan berbagai penelitian para ahli lainnya, diungkapkan bahwa limbah rumput laut merupakan salah satu baku yang sangat baik untuk diolah menjadi pakan dan pupuk organik yang unggul, sehat serta ramah lingkungan. KKN-PPM STIE Muhammadiyah tahun 2018 di Desa Benteng memilih thema sosialisasi pembuatan pakan dan pupuk organik sekaligus mensosialisasikan Permentan nomor 70 tahun 2011 tentang pupuk organik. Hasil yang dicapai adalah tingkat pemahaman dan pengetahuan peserta mengenai ketentuan dan prosedur untuk menjadi produsen dan pelaku usaha di bidang pupuk organik dapat diserap dengan baik demikian pula dengan kemampuan peserta menyerap teknologi pembuatan pakan dan pupuk organik cukup baik/tinggi, hal ini terlihat bahwa dari 35 pesrta yang aktif, terdapat 28 orang yang dapat melakukan dengan baik atau sebesar $80 \%$. Dengan demikian pengembangan pembuatan pakan dan pupuk organik di Desa Benteng Kecamatan Malangke dapat menjadi solusi untuk mengatasi masalah kelangkaan pupuk serta mengatasi dampak pencemaran lingkungan dari limbah rumput laut sekaligus menjadi program strategis bagi Pemerintah Desa untuk memotivasi maysarakat dalam menghasilkan produk pertanian dan perikannan yang sehat.dan ramah lingkungan.
\end{abstract}




\section{Pendahuluan}

Kabupaten Luwu utara merupakan salah satu kabupaten yang mempunyai potensi perikanan yang cukup besar yakni panjang pantai 52,5 kilometer, luas tambak 8.345 Ha, jumlah produksi perikanan mencapai 206.971 ton, produksi rumput laut mencapai 8000 Ha dengan tingkat produksi 143.990ton pertahun tribun lutra.com)

Dari sisi ekonomi hal tentunya menjadi salah satu potensi unggulan pengembangan produksi perikanan di Kabupaten Luwu Utara, namun disisi lain juga terdapat dampak berupa limbah produksi pada berbagai tempat disekitar tambak tempat produksi disekitar tempat penjemuran dan disekitar pergudangan rumput laut. Limbah rumput laut jika tidak tertangani dengan baik maka akan sangat mengganggu masyarakat dan lingkungan sekitarnya.

Peneliti laboratorium Pengujian Mutu Hasil Perikanan (LPMPHP) tertarik untuk mengembangkan proses pembuatan serta teknologi/peralatan pengolahan pupuk organik berbahan dasar rumput laut. Dari pres release LPMPHP diungkapkan bahwa rumput laut selain kaya akan kandungan mineral, nutrien anorganik dan organik, rumput laut juga memiiiki kandungan Hormon Pemacu Tumbuh (HPT) yang tinggi untuk meningkatkan pertumbuhan tanaman. Limbah rumput laut tidak sulit untuk di dekomposisi sama seperti jerami, sorasah dan lain-lain, yang diperlukan hanya media mikroba pengurai untuk mendegradasi serat selulosa mejadi zat yang bisa diserap tanaman seperti EM4, molase dan sebagainya. Bahan limbah rumput laut akan hancur dalam 14 hari sampai dengan 21 hari pengomposan. (Efendi Manan 2006).

Selanjutnya Basmal (2009), Peneliti dari Balai Besar Riset Pengolahan Produk dan Bioteknologi Kelautan dan Perikanan mengemukakan bahwa rumput laut tidak hanya dapat digunakan sebagai bahan pangan tetapi juga dapat digunakan sebagai pupuk organik karena rumput laut banyak mengandung trace mineral ( $\mathrm{Fe}, \mathrm{B}, \mathrm{Ca}, \mathrm{Cu}, \mathrm{Cl}, \mathrm{K}, \mathrm{Mg}$ dan $\mathrm{Mn}$ ) dan juga Zat Pengatur Tumbuhan (ZPT) seperti auksin, sitokinin dan giberilin yang berguna untuk memacu pertumbuhan dan meningkatkan Produksi tanaman.

Limbah rumput laut Gracilaria Sp yang kandungan karbohidrat dan serat yang tinggi serta sumpil yang mengandung kalsium dan protein tinggi merupakan satu potensi sebagai bahan tambahan nutrisi pakan ikan yang dibudidayakan Mustaqim dkk.) Pemahaman dan pengetahuan masyarakat tentang pemanfaatan limbah rumput laut menjadi pakan pupuk organik, hanya sampai pada pembuatan pupuk kompos, masyarakat pada umumnya belum mengetahui proses dan teknologi cara pembuatan pakan dan pupuk organik dalam bentuk Granul/pelet atau cair.

Pada sisi lain Kabupaten Luwu Utara setiap tahunnya sering mengalami masalah kelangkaan pupuk, pada tahun 2018 sesuai dengan Rencana Definitif Kebutuhan Kelompok 
(RDKK) dibutuhkan sebanyak 31.000ton namun yang dialokasikan melalui pupuk subsidi hanya sebesar 21.800 ton. Kekurangan alokasi pupuk sebanyak 9.100ton dari jumlah yang dibutuhkan untuk musim tanam 2018, harus dapat diantisipasi agar tingkat produksi petani dan pembudidaya perikanan tidak tergannggu sekaligus dapat menjadi peluang usaha bagi kelompok masyarakat atau Badan Usaha Milik Desa (BUMDES) untuk memproduksi pupuk dan pakan dengan memanfaatkan limbah rumput laut prosesnya relatif mudah, peralatan sederhana, menghasilkan pupuk murah, sehat, unggul serta ramah lingkungan.

Berdasarkan hal tersebut diatas maka masalah pokok yang dihadapi masyarakat petani dikabupaten Luwu Utara dalam kaitannya dengan kebutuhan pupuk adalah; mengapa masyarakat/petani di Kabupaten Luwu Utara belum memanfaatkan limbah rumput laut sebagai bahan dasar pembuatan pupuk dan pakan organik.

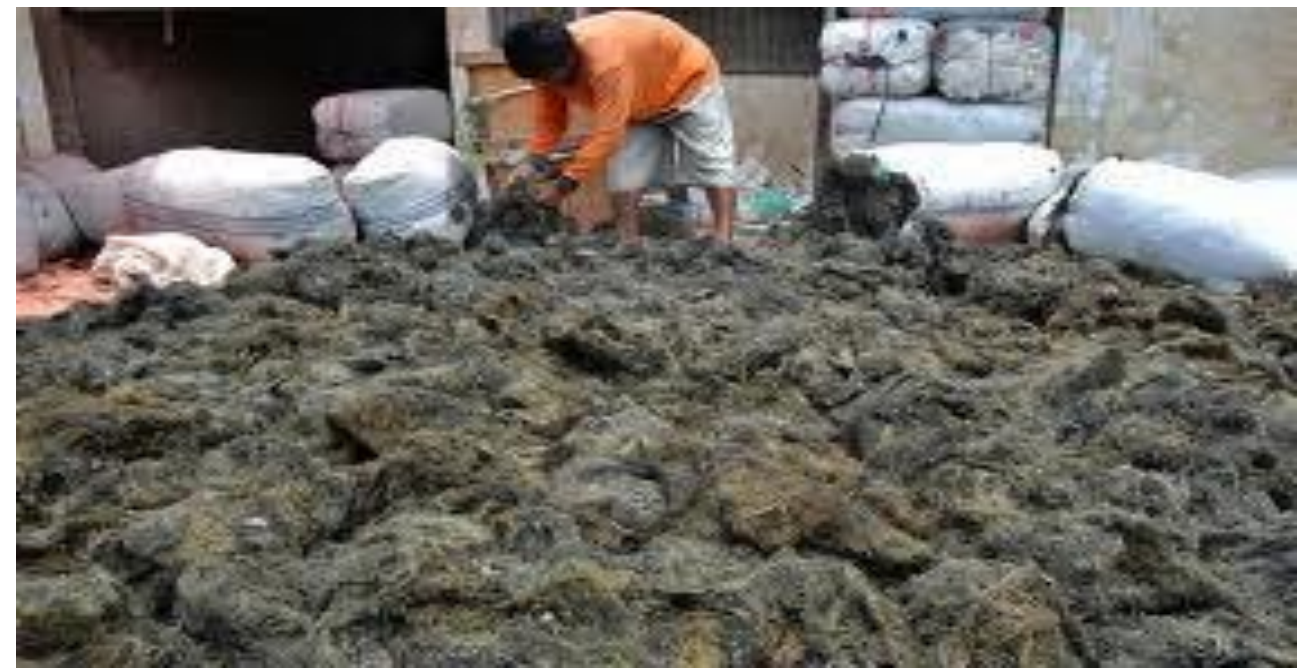

Gambar 1: Limbah Rumput Laut sebagai

Bahan Baku Pupuk Organik

Terhadap hal ini, pengusul melakukan survey awal dan mengidentifikasi masalahnya sebagai berikut.

1. Masyarakat petani dan petambak di Desa Benteng Kecamatan Malangke ssering menghadapi kelangkaan pupuk dan harga yang cukup tinggi.

2. Limbah rumput berpotensi menimbulkan pencemaran lingkungan pada saat panen raya.

3. Masih kurangnya informasi dan pengetahuaan masyarakat mengenai teknologi dan cara Pemanfaatan limbah rumput laut sebagai bahan dasar pembuatan pupuk dan pakan organik.

4. Belum maksimalnya perhatian pemerintah daerah dalam memasyaratkan pertanian Organik. 


\section{Masalah}

Berdasarkan identifikasi dari permasalahan yang dihadapi masyarakat petani di Desa Benteng Kecamatan Malangke Kabupaten Luwu utara dan dalam hal pemenuhan kebutuhan pupuk dan pakan ikan sekaligus untuk mengatasi potensi pencemaran dari limbah rumput laut, maka solusi yang ditawarkan dalam program KKN-PPM STIE Muhammadiyah Palopo tahun 2018 adalah: (1) Melakukan Sosialisasi dan diseminasi teknologi Hasil Penelitian laboratorium Pengujian Mutu Hasil Perikanan (LPMPHP) tentang pemanfaatan teknologi /peralatan pengolahan pupuk organik berbahan dasar rumput laut. (2) Melakukan sosialisasi Peraturan Menteri Pertanian Nomor 70/Permentan/SR.140/10/2011 Tentang Pupuk Organik, Pupuk Hayati Dan Pembenah Tanah, Kedua Kegiatan ini diharapkan akan meningkatkan pemahaman, pengetahuan dan keterampilan kelompok tani dan pembudidaya perikanan tentang cara pembuatan pupuk organik sekaligus pemahaman tentang ketentuan dan prosedur pengadaan, tata cara pendaftaran, pengujian, peredaran, penggunaan, pengawasan dan pemeriksaan terhadap:

a. proses produksi pupuk organik, pupuk hayati dan/atau pembenah tanah;

b. melakukan pemeriksaan terhadap sarana tempat penyimpanan dan cara pengemasan.

c. mengambil contoh pupuk organik, pupuk hayati dan/atau pembenah tanah guna pengujian mutu;

d. memeriksa dokumen dan laporan;

e. melakukan pemeriksaan terhadap pemenuhan persyaratan perizinan pengadaan dan/atau peredaran pupuk organik, pupuk hayati dan/atau pembenah tanah.

\section{Metode}

Kegiatan ini dilakukan dalam bentuk sosialisasi dan diseminasi teknologi yang sederhana dan praktis sehingga mudah diserap oleh peserta dengan menggunakan metode pelatihan sekaligus demonstrasi/eksperimen, penyuluhan serta diskusi. Kegiatan diseminasi ini juga merupakan kaji tindak (action research) dalam rangka mensosialisasikan Peraturan Menteri Pertanian Nomor 70 tahun 2011 serta teknologi effective microorganism untuk mempercepat proses pengolahan /pengomposan rumput laut menjadi pupuk pakan dan organik dengan pendekatan konsep pemberdayaan masyarakat. 


\section{Hasil dan Pembahasan}

Pelaksanaan program pengabdian KKN-PPM dalam kegiatan pemberdyaaan berupa Sosialisasi dan Diseminasi Pemanfaatan Limbah Rumput Laut Sebagai Bahan dasar Pembuatan Pakan dan Pupuk Organik. Melalui beberapa tahapan sebagai berikut;

a. Persiapan Sosialisasil

Persiapan dan pembekalan melibatkan Pusat Penelitian dan Pengabdian kepada Masyarakat (P3M) STIE Muhammadiyah Palopo dan seluruh peserta dalam program KKN-PPM sebelum diterjunkan pada lokasi KKN-PPM, diawali dengan identifikasi dan inventarisasi instansi yang yang menjadi pemateri/narasumber, kelompok masyarakat yang akan menjadi mitra/ psserta, serta kersediaan bahan dan peralatan yang dibutuhkan.

Dari hasil identifikasi awal tersebut ditetapkan bahwa kegiatan KKN-PPM STIE Muhammadiyah Palopo di Desa Benteng akan melakukan kegiatan Sosialisasi dengan melibatkan UPT BBI Rampoang Kota Palopo sebagai nara sumber serta Kelompok Dasawisma, Kelompok Pembudidaya Perkanan dan Mahasiswa KKN-PPM di Desa Benteng sebagai Kelompok sasaran dengan jumlah peserta 40 orang.

Pada kegiatan pembekalan KKN-PPM STIE Muhammadiyah tahun 2018 Dosen Pembimbing Lapangan (DPL) terlebih dahulu mensosialisasikan kepada seluruh mahasiswa peserta KKN sekitar 300 orang mengenai bahan, teknologi dan prosfek pemanfaatan limbah rumput laut untuk diolah menjadi pakan dan pupuk organik.;

b. Pelaksanaan

Berdasarkan hasil observasi dilapangan, maka perencanaan pelaksanaan program dilakukan dengan langkah sebagai berikut :

1) Serah mahasiswa KKN-PPM ke Pejabat daerah setempat (Camat Malangke, Kepala Desa Benteng beserta staf) sebagai tanda resmi KKN-PPM dimulai.

2) Sosialisasi dan Diseminasi dilaksanakan oleh mahasiswa beserta aparat Kantor Desa Benteng di bantu unsur pemuda/karang taruna.

3) Rencana program kerja dan aktivitas mahasiswa di bagi sedemikian rupa sesuai tugas dan peran masing-masing dalam kelompok KKN-PPM

Langkah-langkah yang dilaksanakan dalam program adalah;

- Sosialisasi program dan Kebijakan Pemerintah Daerah termasuk Peraturan menteri pertanian nomor 70 ahun 2011.

- Sosialisasi rencana program Pemerintah Desa oleh Kepala Desa Benteng. 
- Soasialisasi dan disemianasi Teknologi pemanfaatan limbah rumput laut sebagai bahan dasar pembuatan pakan dan pupuk oleh Kepala UPT Balai Benih Ikan (BBI) Dinas Kelautan dan Perikanan Kota Palopo

- Sosialisasi Prosfek Usaha pengembangan produksi Pupuk Organik berbahan dasar rumput laut oleh pengusul/Dosen Pembimbing Lapangan

2. Materi Sosialisasi dan Disemianasi Teknologi

1). Peralaian dan Bahan untuk pembuatan pakan dan Pupuk Organik

Alat-alat yang diperlukan (manual) antara lain :

○ Tempat pembuatan kompos, sebaiknya ada naungan.

○ Sekop,

○ Cangkul garpu

- Gembor Ember

- Lembaran plastik penutup

- Termometer Timbangan

2). Teknologi/ Peralatan Pembuatan Dengan Sistem Mesin Sederhana;

- Tangki air

- Mikser

- Spiner

○ Mesin Penepung

○ Timbangan Digital

○ Mesin Pencetak Pelet/pupuk 

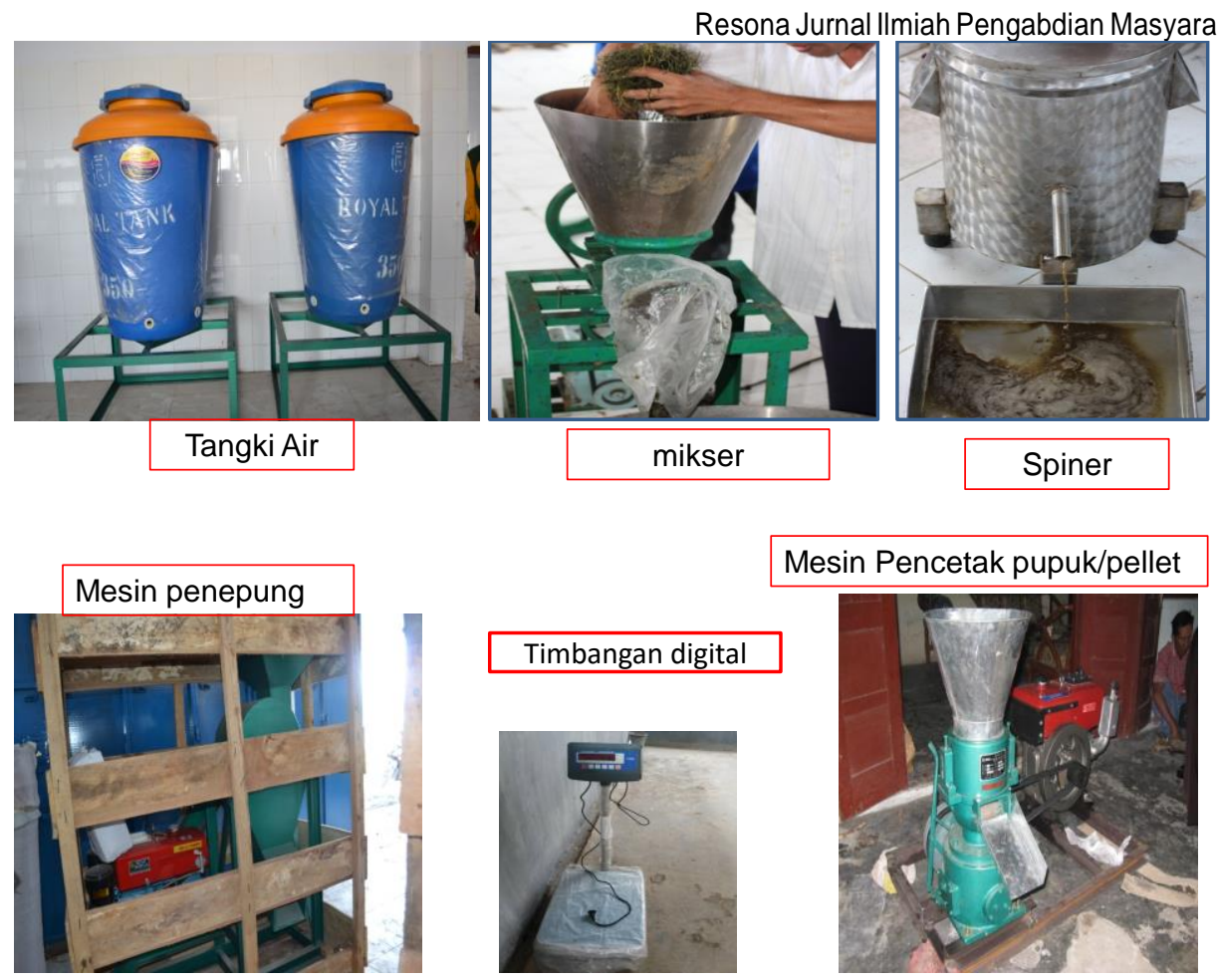

Gambar: Mesin/Peraltan Pengolahn Pakan dan Pupuk Organik

3). Bahan-Bahan Yang Diperlukan :

$\begin{aligned} \circ & \text { Bahan hasil samping perikanan } & =30 \mathrm{Kg} \\ \circ & \text { Sekam padi } & =10 \mathrm{Kg} \\ \circ & \text { Dedak } & 10 \mathrm{Kg} \\ \circ & \text { Kotoran ternak sapi/ayam/kambing dll } & =10 \mathrm{Kg} \\ \circ & \text { Sampah organik Pertanian } & =25 \mathrm{Kg} \\ \circ & \text { Kapur (dolomite) } & =5 \mathrm{Kg} \\ \circ & \text { Hijauan dari rerumputan } & =10 \mathrm{Kg}\end{aligned}$
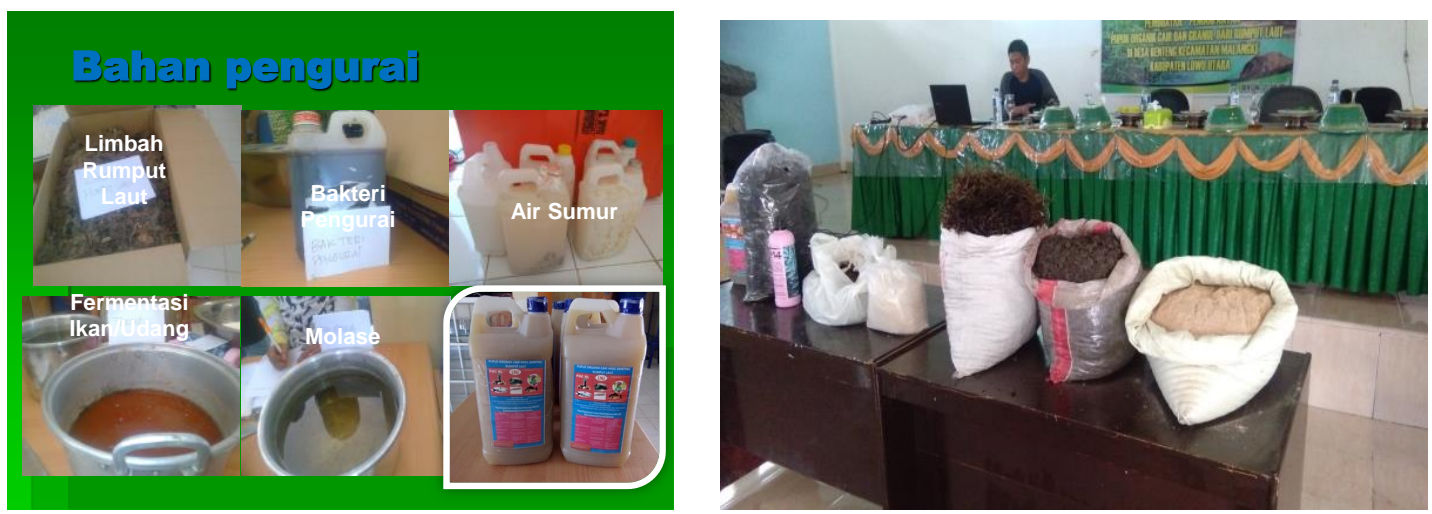

Gambar: Bahan pembuatan Pakan Pupuk Organik 


\section{4). Cara Membuat Kompos}

- Siapkan lahan seluas 10meter persegi untuk tempat pengomposan lebih baik apabila tempat pengomposan diberi peneduh untuk menghindari hujan.

- Buat Bak atau kotak persegi empat dari papan kayu dengan lebar 1 x 1,5 meter, pilih kau dengan lebar 30 x $40 \mathrm{~cm}$.

- Siapkan material organik dari sisa tanaman, bisa dicampur kotoran ternak atau hasil samping perikanan. Cacah bahan organik tersebut hingga menjadi potongan-potongan Kecil smakin keil potongan organik semakin baik tapi jangan samapi terlalu halus, agar aerasi dapat berlangsung sempurna saat pengomposan berlangsung.

- Masukkan bahan organ ikan yang sudah dicacah kedalam bak kayu, kemudian padatkan isi seluruh bak kayu hingga penuh.

Selanjutnya Dalam proses pembuatan pakan ikan terdapat 2 proses pencampuran, yaitu pencampuran bahan-bahan yang berjumlah kecil (pre mixing) dan pencampuran, semua komponen pakan. Bahan-bahan yang berjumlah kecil (mikro ingrident) antara lain; vitamin dan mineral-mineral yang esensial tapi diperlukan dalam jumlah yang sangat sedikit, sehingga diperlukan bahan pengisi yang berat jenisnya mendekati bahanbahan mikro tadi. Pencampuran bahan dengan mesin sederhana dapat digunakan mixer pembuat adonan roti, bahan diaduk sampai merata agar pelet yang dihasilkan memiliki kualitas yang sama pada setiap butirnya. Setelah bercampur menjadi adonan siap dicetak menjadi pelet.

Mesin pencampur bahan (mixer) dan pencampuran dengan tangan Pencetakan pelet menggunakan peralatan sederhana, sebagai contoh mesin pelet buatan lokal, mesin giling daging dapat juga menggunakan mesin briket batu bara. Besar kecilnya ukuran pelet sangat tergantung ukuran lubang cetakan, pada umumnya 1.5, 2 dan $3 \mathrm{~mm}$. Pada peralatan sederhana ini semua bahan yang telah dicampur secara merata, selanjutnya ditambahkan air antara 25 - 30\% atau bila bahan campuran bila dikepal membentuk gumpalan tidak lekas hancur, selanjutnya bahan dicetak menjadi pelet.

Pencetakan pelet dengan mesin sederhana dan pengeringan pelet Proses pengemasan pakan meliputi penimbangan, pengemasan, perekatan, pengkodean dan penjahitan. Setelah dikeringkan pakan harus segera disimpan agar tidak mengalami kerusakan/ penurunan mutu. Disimpaan dalam karung yang diberi lapisan plastik pada bagian dalam karung (iner). 
3. Sosialisasi Peraturan Permentan Nomor 70 Tahun 2011

Salah satu dasar pertimbangan ditetapkannya Peraturan Menteri Pertanian Nomor 70/Permentan/SR.140/10/2011 Tentang Pupuk Organik, Pupuk Hayati Dan Pembenah Tanah ada lah untuk melindungi kelestarian fungsi lingkungan, keanekaragaman hayati, konsumen/pengguna, dan memberikan kepastian usaha bagi produsen/pelaku usaha pupuk organik, pupuk hayati dan pembenah tanah yang diedarkan di wilayah negara Republik Indonesia harus memenuhi standar mutu dan terjamin efektivitasnya, Oleh karena itu melalui kegiatan KKN-PPM STIE Muhammadiyah Palopo tahun 2018 merasa tertarik mmensosialisasikan Peraturan Menteri ini dan menjadi salah satu materi yang disosialisasikan agar masyarakat mengetahui dan memahami ketentuan dan prosedur yang harus dipenuhi untuk menjadi produsen dan pelaku usaha dibidang produksi pupuk organik.

1). Pengadaan

a. Pengadaan pupuk organik, harus dilakukan oleh badan usaha bidang sarana produksi pertanian.

b. Badan usaha yang akan memproduksi pupuk organik harus mendapat izin dari Bupati/ Walikota setempat.

c. Bupati/Walikota dalam memberikan izin) wajib memerhatikan peraturan perundang-undangan di bidang perindustrian.

d. Pupuk organik, yang diproduksi sebagaimana harus berasal dari formula pupuk organik, hasil rekayasa.

e. Formula pupuk organik harus memenuhi standar mutu serta terjamin efektivitasnya harus memenuhi Persyaratan teknis minimal sebagaimana seperti tercantum pada Lampiran sebagai bagian tidak terpisahkan dengan Peraturan ini.

2). Persyaratan Pendaftaran

Untuk mendapatkan nomor pendaftaran prmohonan pendaftaran formula pupuk organik harus melengkapi:

a. Akte pendirian perusahaan dan perubahannya;

b. Surat Izin Usaha Perdagangan (SIUP) dan/atau Tanda Daftar Usaha Perdagangan (TDUP) dan/atau Surat Persetujuan Penanaman Modal;

c. Nomor Pokok Wajib Pajak (NPWP);

d. Surat keterangan domisili/ Kartu Tanda Penduduk (KTP); 
Resona Jurnal Ilmiah Pengabdian Masyarakat, (2018)

e. Pernyataan yang berhak menandatangani surat dalam rangka pendaftaran dan perizinan;

f. Konsep label kemasan;

g. Surat tanda bukti pendaftaran merek/sertifikat merek dari instansi yang berwenang; da

h. Melampirkan sertifikat SNI bagi pupuk yang telah mendapatkan sertifikat SNI dari Badan Standardisasi Nasional (BSN).

i. Pendaftaran pupuk organik dilakukan oleh pemilik formula yang bersangkutan atau kuasanya

j. Label kemasan ditulis dalam Bahasa Indonesia, paling kurang memuat: (a). nama dagang; (b). nomor pendaftaran; (c)kandungan hara (khusus untuk pupuk) dengan batas toleransi yang ditetapkan dalam Peraturan ini sebagaimana pada Lampiran;( d). isi atau berat bersih; (e). masa edar;( f). nama dan alamat produsen atau importir; (g). tanggal, bulan dan tahun produksi; (h). petunjuk penggunaan.

k. Pupuk organik, yang didaftarkan harus diberikan penamaan tersendiri, yang merupakan identitas dari setiap formula yang akan diedarkan.

1. Satu formula pupuk organik, tidak boleh didaftarkan oleh pemohon dengan menggunakan nama dagang formula/ merek yang sama atau hampir sama dengan nama dagang/formula lain yang terdaftar dan hanya menggunakan satu nama dagang formula/merek

m. Penamaan harus memenuhi persyaratan sebagai berikut: (a) tidak berkaitan dengan nama unsur/ jenis yang menunjukkan formula pupuk organik, formula pupuk hayati dan/atau formula pembenah tanah; (b). setiap penamaan formula pupuk organik harus dilampiri bukti telah melakukan pendaftaran merek dari instansi berwenang sesuai ketentuan peraturan perundang-undangan tentang Hak Kekayaan Intelektual (HKI); dan (c). penamaan formula tidak bersifat agitatif seperti misalnya kata-kata "dahsyat", "hebat", "super" atau "ampuh".

3). Tata Cara Pendaftaran

Permohonan pendaftaran pupuk organik, diajukan secara tertulis kepada Direktur Jenderal melalui Kepala Pusat dengan dilampiri persyaratan administrasi Kepala Pusat dalam jangka waktu paling lama 3 (tiga) hari kerja terhitung sejak menerima permohonan harus sudah selesai melakukan pemeriksaan kelengkapan 
persyaratan dan memberikan jawaban ditolak atau diterima Permohonan ditolak apabila masih ada kekurangan persyaratan sebagaimana Penolakan oleh Kepala Pusat disampaikan kepada pemohon dengan disertai alasan penolakan secara tertulis .

Permohonan diterima apabila persyaratan telah lengkap dan benar.) Permohonan yang diterima) selanjutnya oleh Kepala Pusat disampaikan secara tertulis kepada Direktur Jenderal untuk dimohonkan proses teknis,

Pengujian Direktur Jenderal dalam jangka waktu paling lambat 3 (tiga) hari kerja terhitung sejak tanggal menerima permohonan harus sudah menerbitkan surat kepada pemohon untuk melakukan uji mutu. Pengujian mutu dilakukan oleh Lembaga yang terakreditasi atau ditunjuk.

4). Pengujian

Dalam melakukan pengujian mutu harus mengikuti metode standar seperti tercantum pada Lampiran VII sebagai bagian tidak terpisahkan dengan Peraturan ini. Hasil Pengujian mutu oleh Laboratorium Uji disampaikan kepada Direktur Jenderal dengan tembusan kepada pemohon, untuk dilakukan penilaian teknis hasil uji mutu sesuai dengan persyaratan SNI atau Persyaratan Teknis Minimal Pupuk Organik, seperti tercantum pada Lampiran VIII sebagai bagian tidak terpisahkan dengan Peraturan ini.

Penilaian teknis dilakukan Direktur Jenderal dalam jangka waktu paling lama 3 (tiga) hari kerjaUntuk formula pupuk organik yang telah memiliki sertifikat SNI tidak dilakukan pengujian mutu. Formula pupuk organik, yang telah memiliki sertifikat SNI untuk mendapatkan nomor pendaftaran harus melampirkan sertifikat SNI sesuai peraturan perundang-undangan.

Apabila penilaian teknis hasil pengujian mutu tidak memenuhi persyaratan, Direktur Jenderal memberitahukan kepada pemohon melalui Kepala Pusat secara tertulis disertai alasan sebagai bagian tidak terpisahkan dengan Peraturan ini, selanjutnya pemohon dapat mengajukan permohonan pengujian mutu ulang.

Apabila penilaian teknis hasil pengujian mutu memenuhi persyaratan, Direktur Jenderal menerbitkan surat kepada pemohon untuk melaksanakan pengujian efektivitas menggunakan formulir model- 6 seperti tercantum pada Lampiran X sebagai bagian tidak terpisahkan dengan Peraturan ini. (

Uji efektivitas dilakukan oleh Lembaga Pengujian Efektivitas seperti 
tercantum pada Lampiran XI sebagai bagian tidak dimaksud dalam melakukan pengujian efektivitas mengikuti metode standar seperti tercantum pada Lampiran XII sebagai bagian tidak terpisahkan dengan Peraturan ini. Laporan hasil uji efektivitas dan rekomendasi uji efektivitas oleh lembaga uji disampaikan kepada Direktur Jenderal untuk dilakukan penilaian teknis hasil uji efektivitas sesuai dengan Ketentuan Lulus Uji Efektivitas pupuk organik seperti tercantum pada Lampiran XIII sebagai bagian tidak terpisahkan dengan Peraturan ini.

Lembaga Uji Efektivitas dalam menyusun laporan uji efektivitas) mengikuti metode standar Lembaga Uji Efektifitas dalam menyusun rekomendasi hasil uji efektivitas mengikuti metode standar seperti tercantum pada Lampiran XV. Direktur Jenderal dalam waktu paling lama 10 (sepuluh) hari kerja telah selesai melakukan penilaian teknis hasil uji efektivitas sebagaimana dimaksud pada ayat (5) Permentan nomor 70 tahun 2011.

Apabila dari penilaian teknis hasil pengujian efektivitas memenuhi persyaratan, selanjutnya Direktur Jenderal atas nama Menteri dalam jangka waktu paling lama 14 (empat belas) hari kerja, menerbitkan nomor pendaftaran. Nomor pendaftaran berlaku untuk jangka waktu selama 5 (lima) tahun, dan dapat didaftar ulang untuk jangka waktu 5 (lima) tahun berikutnya.

5). Peredaran dan Penggunaan

Pupuk organik harus memenuhi standar mutu, terjamin efektivitasnya, diberi label dan didaftar, harus dicantumkan dalam kemasan kedap air yang penempatannya mudah dilihat, dibaca dengan jelas dan tidak mudah rusak. Jenis dan penggunaan pupuk organik, dilakukan dengan memerhatikan produktivitas dan pelestarian fungsi lingkungan.

Jenis dan tata cara penggunaan pupuk organik diatur dengan Peraturan tersendiri. Apabila dalam penggunaan pupuk organik terbukti menimbulkan dampak negatif terhadap kesehatan manusia dan/atau fungsi lingkungan hidup, nomor pendaftaran dicabut

\section{6). Pengawasan}

Pengawasan pupuk organik dillakukan pada tingkat rekayasa formula, pengadaan, peredaran dan penggunaan. Pengawasan dilakukan secara periodik setiap 6 (enam) bulan sekali. Pengawasan pupuk organik dilakukan sebagai berikut: 
a. Pada tingkat rekayasa formula, menjadi kewenangan Menteri;

b. Pada tingkat pengadaan, peredaran dan penggunaan, menjadi kewenangan bupati/walikota setempat di bawah koordinasi gubernur.

c. Pengawasan atas pengadaan, peredaran dan penggunaan pupuk organik dilakukan secara terpadu di bawah koordinasi Direktur Jenderal dan Gubenur.

d. Pengawasan tingkat rekayasa oleh petugas pengawas pupuk.

Petugas pengawas pupuk melakukan pengawasan terhadap penerapan standar mutu pupuk organik, pupuk hayati dan/atau pembenah tanah, pelaksanaan pengujian mutu dan efektivitas serta penggunaan nomor pendaftaran. Petugas pengawas pupuk adalah Pegawai Negeri Sipil di lingkungan Kementerian Pertanian yang diangkat dan diberhentikan oleh Menteri.)

Pengawasan tingkat pengadaan, peredaran dan penggunaan sebagaimana dimaksud dilakukan oleh petugas pengawas pupuk yang ditunjuk Bupati/Walikota. Petugas pengawas pupuk adalah pegawai negeri sipil di lingkungan instansi yang bertanggung jawab dalam pelaksanaan tugas pokok dan fungsi di bidang pembinaan dan pengawasan terhadap pengadaan, peredaran dan penggunaan pupuk

\section{Evaluasi Dan Monitoring}

Kegiatan evaluasi dan monitoring dilakukan secara menyeluruh mulai dari saat pembekalan mahasiswa sampai pada saat berakhirnya kegiatan. Sebelum dilakukan Ssosialisasi, terlebih dahulu dilakukan penelusuran dan survey informasi mengenai kebutuhan Mahasiswa KKN-PPM terkait dengan pengetahuan dan keterampilan pemanfaatan limbah rumput laut sebagai bahan dasar pembuatan pakan dan pupuk organikdalam bidang

Proses soasialisasi Permentan nomor 70 tahun 2011 dan soasialisas pemanfaatan limbah rumput laut menjadi pupuk organik berlangsung penuh dinamika yang ditandai dengan tanya jawab anatara pelatih dan para mahasiswa KKN-PPM dalam suasana santai. Banyak diantara mereka yang aktif membuat/mencoba melakukan simulasi pembuatan pupuk organik, namun masih ada yang menginginkan dan membutuhkan bimbingan secara intensif untuk dapat memproduksi secara mandiri pupuk ang dibutuhkan.

Hasil yang didapat kemudian diimplementasikan dikalangan mereka sendiri baik mahasiswa maupun masyarakat peserta sosialisasi. termasuk P3M STIE 
Muhammadiayah Palopo juga perlu melakukan tindak lanjut dalam bentuk kerja sama (MOU) atau pembinaan secara permanen dengan pemerintah desa termasuk pendampingan dalam mengikuti ketentuan dan prosedur untuk memproduksi pupuk organik sesuai Peraturan Menteri Pertanian.

\section{Simpulan dan Saran}

Pemberdayaan sumber daya manusia harus dilandasi dengan kondisi eksisting di masyarakat. petani dan pembudidaya perikanan dicitrakan sebagai individu masyarakat marjinal, padahal pada hakekatnya mereka adalah pemilik faktor produksi berupa yang belum maksimal dalam memperoleh pendapatan untuk meningkatkan kesejahteraannya. Rendahnya tingkat pendapatan dan kesjahteraan petani dan pembudidaya perikanan saat ini disebabkan oleh tingginya biaya produksi terutama pupuk dan pakan.

Untuk mewujudkan peran Kabupaten Luwu Utara sebagai salah satu sentra Pengenbangan Produksi perikanan dan rumput laut maka perlu didukung dengan ketersediaan pupuk yang cukup terutama pupuk organik untuk menghasilkan produk pertanian dan perikanan yang sehat dan ramah lingkungan. Terhadap hal ini maka melalui Kepala Desa Benteng disarankan untu memprakarsai membentuk "SATGAS" pemberdayaan masyarakat secara terpadu lintas sektor yang dituangkan dalam bentuk kerja sama atau MOU dengan nama "SATGAS” Gerakan Pemanfaatan Limbah rumput sebagai Bahan pembuatan Pakan dan Pupuk organik.

\section{Ucapan Terima Kasih}

Ucapan terima kasih kepada Lembaga Penelitian dan Pengabdian Masyarakat (LPPM) STIE Muhammadiyah Palopo, prodi Ekonomi Pembangunan, Pemerintah Desa Benteng Kecamatan Malangke dan Kabupaten Luwu Utara yang telah memberikan kesempatan serta memfasilitasi terselenggaranya kegiatan pengabdian pada masyarakat. Demikian, kegiatan dapat berjalan sesuai dengan target waktu yang ditentukan.

\section{Daftar Pustaka}

[1]. Basmal Jamal, Prospek Pemanfaatan Rumput Laut Sebagai Bahan Pupuk Organik, Jurmal Squalen Vol 4 No. 1, Mei 2009.

[2]. Gubali Hayatiningsih, Puluhulawa Jusdin, Pemanfaatan Limbah Rumput Laut Sebagai Bahan Pembuatan Pupuk Organik, KKS Pengabdian, Lembaga Penelitian dan 
Resona Jurnal Ilmiah Pengabdian Masyarakat, (2018)

Pengabdian, Universitas Negeri Gorontalo (UNG), 2017

[3]. Kementerian Pertanian RI (2011), Peraturan Menteri Pertanian Nomor 70/Permentan/Sr.140/10/2011 Tentang Pupuk Organik, Pupuk Hayati Dan Pembenah Tanah

[4]. Mustaqim dkk., Pengolahan Limbah Rumput Laut Sebagai alternatif Pakan Ternak dan Ikan, Univesitas Panca Sakri, Tegal.

[5]. Sutikno Erik, Pakan buatan Ikan Bandeng, Dirjen Perikanan Budidaya Balai Besar Pengembangan Budidaya Air Payau Jepara, diperbanyak oleh Pusat Penyuluhan Kelautan dan Perikanan Kementerian Kelautan dan Perikanan, 2011.

[6]. www/mekanisasikp.web.id, Loka Penelitian dan Pengembangan Mekanisasi Pengelolaan Hasil Perikanan (LPP-MPHP), diakses 24 januar2018

[7]. http;//isroi.wordpress.com, Pupuk Organik Granul Sebuah Petunjuk Praktis, posted on may 2013, diakses tanggal 24 januari 2018 